\title{
FACTORS AFFECTING ON ADHERENCE TO THE PRESCRIBED DRUGS IN DIABETIC PATIENTS VISITING A TERTIARY CARE CENTRE
}

\author{
Bijay Thapa, Paras Kumar Pokharel,Ishwori Sharma Poudel, Sanjib Kumar \\ Sharma ,Pramod Mohan Shyangwa, Himal Sangraula and Archana Sharma
}

\begin{abstract}
Introduction: Non-adherence to prescribed medications is a major problem worldwide in most of the diseases. It is the irregularity and discontinuation of medicine taking behavior of patients. Various studies on this subject show that adherence is about $50 \%$ for medications in chronic diseases like diabetes and much lower for lifestyle prescriptions.
\end{abstract}

Objective: To elucidate the possible factors of non-adherence.

Material and Methods: A cross sectional study was carried out from February 2008 to July 2009 at diabetic clinic of Department of Medicine at BPKIHS, Dharan, Nepal, a Tertiary Care Centre. Three hundred diabetic patients aged 24 years and above, taking treatment for diabetes for at least six month were included using convenient sampling. Verbal and written consent was taken. Data were entered into SPSS 14.0 and relevant statistical tools applied.

Results: The prevalence of adherence was only $52 \%$ among patients. Factors that were independently associated with non-adherence were: male gender $(\mathrm{OR}=1.2395 \% \mathrm{CI}=0.778$ $1.93)$, longer time since last visit to a health worker $(\mathrm{OR}=0.67,95 \% \mathrm{CI}=0.42-1.07)$, those who were on alternative medicine, number of medicines taken due to multiple diseases. Ten patients had diabetic retinopathy of both type: non proliferative and proliferative.

Conclusions: Regular using of medicine during diabetic treatment phase was minimal. There is a need to improve it through strategies which will help patients to understand about the outcome by becoming adherent and visiting the health worker as advised. Further studies should be done to find out why patients were not complying with treatment so as to improve their adherence.

Key words: adherence, Prescribed medications, diabetes

\section{Introduction}

Non-adherence to prescribed medications has been and continues to be a major problem worldwide. Various studies on this subject show that adherence is about $50 \%$ for medications in chronic diseases and much lower for lifestyle prescriptions ${ }^{1,2}$. Diabetes is one of the most psychologically and behaviorally demanding disease among the chronic diseases ${ }^{3}$. It requires frequent self monitoring of blood glucose, dietary modifications, exercise, and administration of medication on schedule ${ }^{3-5}$. Studies have emphasized the importance of achieving optimal glucose control through strict 
adherence to medications, diet, and exercise in order to minimize serious long term complications ${ }^{2}, 3, \quad 6$. These complications affects patient's quality of life, increases mortality, morbidity and economic cost to society $2,3,7$. It is imperative that patients adhere to their prescribed regimens to minimize the burden of the disease on the health systems ${ }^{2,7}$.

Non-adherence in chronic diseases has been described as taking less than $90 \%$ of the prescribed treatment ${ }^{1}$. Previous studies have found adherence to Diabetes treatment generally to be sub-optimal ranging from 23 to $77 \%{ }^{2,8-11}$. In addition, these studies have also generated varied results of factors associated with non-adherence to diabetes treatment. A number of health service and medicines related factors that have been cited in the literature include: poor patient provider relationship, longer time since diabetes, education, side effects of the medication and pill burden ${ }^{3,9,12,13}$.

\section{Methods}

This was a cross sectional study with quantitative methods of data collection. The study was approved by the ethical committee of BPKIHS, Dharan, Nepal.

\section{Patients}

Patients for this study were obtained from Diabetic Clinic, Department of Internal Medicine BPKIHS, Dharan, a tertiary centre and teaching hospital in Nepal. The hospital is located within Dharan, Eastern Part of the country. It operates an out-patients diabetic clinic once a week and has in-patient facilities where medical care is provided throughout the week. Convenient sampling technique was used to choose the patients as needed. Patients were selected on each clinic by writing down the names and addresses after taking verbal and written consent with explanation. Sample included only Type 2 diabetic patients who were diagnosed for more than 6 months. Thereafter, they were followed up by door to door survey.

Inclusion criteria: The main inclusion criteria were:

1. Having Type 2 diabetes diagnosed for more than 6 months

2. Verbal consent as well as written consent to participate in the study.

\section{Data collection}

Interviewer used a pre-tested semi structured questionnaire. Variables included: health education attendance, number of prescribed medications, route of drug administration, patient's self-rating of how well they understood their drug regimens, adverse drug reactions, patient's affordability of the prescribed drugs, duration of diabetes and use of alternative medicines. The patients' health cards were used to ascertain their medication regimens. Non adherence was assessed using patients self-reports and counting their drug strip by the interviewer and asking the pattern their medication intake in the week preceding the interview. Also patients were asked to recall if they missed any doses of medication on a day by day basis over a period of one week. The number of tablets missed was calculated based on the prescribed dose. Patients who reported taking less than $90 \%$ of their prescribed diabetes medicines were considered not to be adhering to treatment. Diabetic retinopathy was assessed by fundus examination. In statistical analysis, descriptive statistics were used for general description of study participants and to obtain the prevalence of non-adherence to diabetes treatment. Odds ratios, their $95 \%$ confidence intervals and $p$-values were obtained. Independent variables whose p-values did not exceed 0.5 were selected for the multivariate 
analysis in order to determine which variables were independently associated with nonadherence. Logistic regression was used for univariate and multivariate analysis. SPSS 14.0 was used for statistical analysis.

\section{Results}

\section{Table1. Association between demographic characteristics and non-adherence}

\begin{tabular}{|c|c|c|c|c|c|}
\hline Variables & Non-ad & ierence & OR & $95 \%$ CI & pvalue \\
\hline $\begin{array}{l}\text { Sex } \\
\text { Male } \\
\text { Female }\end{array}$ & $\begin{array}{ll}71 & (50.7) \\
73 & (45.6)\end{array}$ & $\begin{array}{l}69(49.3) \\
87(54.4)\end{array}$ & $\begin{array}{l}1.23 \\
1.00\end{array}$ & $0.778-1.93$ & 0.379 \\
\hline $\begin{array}{l}\text { Age } \\
<40 \text { years } \\
40-49 \text { years } \\
50-59 \text { years } \\
60-69 \text { years } \\
>70 \text { years }\end{array}$ & $\begin{array}{l}6(20.0) \\
18(40.0) \\
39(43.8) \\
51(60.0) \\
30(58.8)\end{array}$ & $\begin{array}{ll}24 & (80.0) \\
27 & (60.0) \\
50 & (56.2) \\
34 & (40.0) \\
21 & (41.2)\end{array}$ & $\begin{array}{c}0.175 \\
0.467 \\
0.546 \\
1.05 \\
1.00\end{array}$ & $\begin{array}{l}0.06-0.50 \\
0.20-1.05 \\
0.27-1.09 \\
0.51-2.12\end{array}$ & $0.001 * *$ \\
\hline $\begin{array}{l}\text { Literacy } \\
\text { Illiterate } \\
\text { Literate }\end{array}$ & $\begin{array}{c}20(69.0) \\
124(45.8)\end{array}$ & $\begin{array}{c}9(31.0) \\
147(54.2)\end{array}$ & 2.634 & $1.15-5.99$ & $0.017 *$ \\
\hline $\begin{array}{l}\text { Education level } \\
\text { No schooling } \\
\text { Up to secondary } \\
\text { Above secondary }\end{array}$ & $\begin{array}{l}80(55.6) \\
51(44.3) \\
13(31.7)\end{array}$ & $\begin{array}{l}64(44.4) \\
64(55.7) \\
28(68.3)\end{array}$ & $\begin{array}{l}2.69 \\
1.71 \\
1.00\end{array}$ & $\begin{array}{l}1.29-5.61 \\
0.80-3.64\end{array}$ & $0.016^{*}$ \\
\hline $\begin{array}{l}\text { Marital status } \\
\text { Married } \\
\text { Widower }\end{array}$ & $\begin{array}{c}130(49.1) \\
14(40.0)\end{array}$ & $\begin{array}{c}135(50.9) \\
21(60.0)\end{array}$ & 1.44 & $0.705-2.96$ & 60.313 \\
\hline $\begin{array}{l}\text { Occupation } \\
\text { Unemployed } \\
\text { Employed }\end{array}$ & $\begin{array}{c}117(50.6) \\
27(18.8)\end{array}$ & $\begin{array}{c}114(49.4) \\
42(60.9)\end{array}$ & 1.59 & $0.923-2.76$ & 6.093 \\
\hline $\begin{array}{l}\text { Main occupation } \\
\text { Farming } \\
\text { Police/military } \\
\text { Prof/technical } \\
\text { Business } \\
\text { Others }\end{array}$ & $\begin{array}{l}34(55.7) \\
39(58.2) \\
13(28.9) \\
18(45.0) \\
40(46.0)\end{array}$ & $\begin{array}{l}27(44.3) \\
28(41.8) \\
32(71.1) \\
22(55.0) \\
47(54.0)\end{array}$ & $\begin{array}{l}1.47 \\
1.23 \\
0.56 \\
1.17 \\
1.00\end{array}$ & $\begin{array}{l}0.75-2.89 \\
0.67-2.51 \\
0.26-1.23 \\
0.54-2.56\end{array}$ & $0.025^{*}$ \\
\hline
\end{tabular}

The adherence was higher in female than in male $(54.4 \%$ Vs $49.3 \%)$. The highest adherence was found in the age $<40$ years comprising $80 \%$. Only one fifth of respondents in this age group were non adherent. This was followed by the age group $40-49$ years $(60 \%), 50-59$ years $(56 \%)$ and in age group from 60-69 years comprising $40 \%$. Hence, it was seen that the level of adherence was decreasing with the increasing age. The reason for this may be that as the age increases, one tends to become less optimistic. It was also seen that after 70 years of age they were again more adhered to the medications which may be because of the involvement of the caretakers. There was 0.175 times less chance of non- adherence in the age group $<40$ years as compared to $>70$ years. Similarly, there was 0.467 and 0.546 i.e. two times less chance of non adherence in the age group 40-49 years and 50-59 years respectively, but not significant. Therefore, positive relationship was seen in age and non adherence i.e. as the age of the patients increased, the percentage of non- adherence also increased up to the age of 70 years after which there was a slight decrease after the age of 70. Non adherence was seen more among illiterates in which more than two third (69\%) were not taking medicines regularly. Adherence was higher in the literate group. In this study it was seen that the literate people $54.2 \%$ were more adherent than illiterate ones $31 \%$ which was statistically significant $(\mathrm{P}=0.017, \quad \mathrm{OR}=2.63$ in $95 \% \quad \mathrm{CI}=1.15 \quad-$ 5.99).Adherence in the literate group was double of that of illiterate group. There was a negative association between the level of education and non adherence. There were 2.69 times chances of non adherence in no schooling group than above secondary level $(\mathrm{OR}=2.69, \mathrm{CI}=1.29-5.61)$. Hence, this shows that education increases adherence. Adherence pattern was almost similar in the married and unmarried groups. There was no relationship regarding marital status and adherence. Occupation wise, adherence in technically employed person was found to be more $(71 \%)$ followed by businessman, farmers and police/military having 55\%, 44\% and $41 \%$ respectively. 
Table 2 association of various factors and non-adherence

\begin{tabular}{|c|c|c|c|c|c|}
\hline & $\begin{array}{r}\text { Non-a } \\
\text { Yes [n, } \\
{[n}\end{array}$ & $\begin{array}{l}\text { dherence } \\
(\%)] \text { No } \\
(\%)]\end{array}$ & $\begin{array}{l}\text { Odds } \\
\text { ratio }\end{array}$ & $\begin{array}{c}95 \% \\
\text { CI }\end{array}$ & p- value \\
\hline $\begin{array}{l}\text { Get medicine } \\
\text { Buy themselves } \\
\text { Reimburse }\end{array}$ & $\begin{array}{ll}83 & (42.1) \\
61 & (59.2)\end{array}$ & $\begin{array}{c}114(57.9) \\
42(40.8)\end{array}$ & $\begin{array}{l}0.50 \\
1.00\end{array}$ & $\begin{array}{c}0.30 \\
0.81\end{array}$ & $0.005 *$ \\
\hline $\begin{array}{l}\text { Buy in same } \\
\text { shop } \\
\text { Yes } \\
\text { No }\end{array}$ & $\begin{array}{l}7(18.9) \\
76(47.5)\end{array}$ & $\begin{array}{l}30(81.1) \\
84(52.5)\end{array}$ & $\begin{array}{l}0.25 \\
1.00\end{array}$ & $\begin{array}{l}0.10- \\
0.62\end{array}$ & $0.002 *$ \\
\hline $\begin{array}{ll}\text { Price } & \text { of } \\
\text { medicine } & \\
\text { Affordable } & \\
\text { Expensive } & \end{array}$ & $\begin{array}{c}23(36.5) \\
101 \\
(51.3)\end{array}$ & $\begin{array}{l}40(63.5) \\
96(48.7)\end{array}$ & $\begin{array}{l}0.54 \\
1.00\end{array}$ & $\begin{array}{r}0.30- \\
0.98\end{array}$ & $0.041 *$ \\
\hline $\begin{array}{l}\text { Others disease } \\
1 \text { disease } \\
>2 \text { disease }\end{array}$ & $\begin{array}{c}115 \\
(45.3) \\
29(63.0)\end{array}$ & $\begin{array}{c}139(54.7) \\
17(37.0)\end{array}$ & $\begin{array}{l}0.48 \\
1.00\end{array}$ & $\begin{array}{l}0.25- \\
0.92\end{array}$ & $0.026 *$ \\
\hline $\begin{array}{l}\text { Duration with } \\
\text { Diabetes } \\
6 \mathrm{~m}-1 \text { year } \\
2-4 \text { years } \\
5-10 \text { years } \\
>10 \text { years }\end{array}$ & $\begin{array}{ll}17 & (35.4) \\
25 & (36.8) \\
53 & (56.4) \\
49 & (54.4)\end{array}$ & $\begin{array}{l}31(64.6) \\
43(63.2) \\
41(43.6) \\
41(45.6)\end{array}$ & $\begin{array}{l}0.46 \\
0.49 \\
1.08 \\
1.00\end{array}$ & $\begin{array}{c}0.22- \\
0.95 \\
0.26- \\
0.93 \\
0.60- \\
1.93\end{array}$ & $\begin{array}{c}0.035 \\
0.028 \\
0.791 \\
0.014 *\end{array}$ \\
\hline $\begin{array}{l}\text { No. of drugs } \\
1 \text { medicine } \\
2 \text { medicines } \\
>3 \text { medicines }\end{array}$ & $\begin{array}{c}8(13.3) \\
25(37.3) \\
111(64.2 \\
)\end{array}$ & $\begin{array}{l}52(86.7) \\
42(62.7) \\
62(35.8)\end{array}$ & $\begin{array}{c}0.090 \\
0.328 \\
1.00\end{array}$ & $\begin{array}{c}0.04- \\
0.20 \\
0.17- \\
0.61\end{array}$ & $\begin{array}{c}0.000 * * \\
0.000 \\
0.000\end{array}$ \\
\hline $\begin{array}{ll}\begin{array}{l}\text { Response of } \\
\text { family }\end{array} \\
\text { Positive } \\
\text { Negative }\end{array}$ & $\begin{array}{c}141 \\
(48.1) \\
3(42.9)\end{array}$ & $\begin{array}{c}152(51.9) \\
4(57.1)\end{array}$ & $\begin{array}{l}1.23 \\
1.00\end{array}$ & $\begin{array}{r}0.27- \\
5.62\end{array}$ & 0.783 \\
\hline
\end{tabular}

$*=p$ value significant

${ }^{* *}=p$ value highly significant.

According to the table no. 2 regular medicine or adherence was seen more (58\%) among the respondents who bought medicines by themselves than those who got medicines reimbursed $(41 \%)$ which was statistically significant $(\mathrm{OR}=0.5,95 \%, \mathrm{CI}=0.30-0.81$, $\mathrm{P}=0.005)$. Those who bought medicines from one shop regularly showed more adherences (81\%) compared to those who bought from different shops randomly $(52 \%)$. $(\mathrm{OR}=0.5$,
$95 \% \mathrm{CI}=0.10-0.62, \quad \mathrm{P}=0.002)$.As stated earlier, most of the respondents in this study were ex-army personnel who got their medicines reimbursed. Price was also one of the main factors which played an important role for non adherence. More than half (51\%) were non adherent because of expensive medicines and only $36.5 \%$ were non adherent despite the cost. It showed that non adherence was directly related to the cost of the medicine $(\mathrm{OR}=0.54, \mathrm{CI}=0.30-0.98, \mathrm{P}=0.041)$. Patients with multiple systemic illnesses were more non adherent (63\%) than single diseased. Those who had only one coexisting disease were more adherent $(54.7 \%)$ than that with multiple systemic illnesses. In this study about 18 different diseases were found among respondents which were not shown on the table.

Most coexisting disease was hypertension followed by respiratory system related diseases and connective tissue disorders. Adherence was seen more (64.6\%) among those with diabetes for less than a year as compared to those with more than 10 years (63.2\%). Low adherence was seen in groups who were diagnosed between the ages of 5-10 years $(43.6 \%)$.Number of drugs consumed by the patients had significant relation with non adherence. It showed that the adherence decreased significantly as the number of drugs increased. Those who had to take more than 3 drugs were more likely to forget medicine by double (87\% Vs 36\%)as compared to those who took only 1 medicine $(\mathrm{P}=0.000, \quad \mathrm{OR}=0.090, \quad 95 \% \mathrm{CI}=0.04-0.205)$. Almost all respondents had family support, be it mental, physical or social.98\% had positive family response, out of whom, adherence was seen in 52\% and non adherence in $48 \%$ while, $2 \%$ had negative family response where $57.1 \%$ were adherent and $43 \%$ non adherent. This difference was not significant $(\mathrm{P}=0.783)$. There were 10 cases of diabetic retinopathy or proliferative type comprising 3 patients and 7 
of non proliferative type and were on regular follow up which was not shown in the table.

\section{Discussion}

Over the past few decades we have witnessed several phases in the development of approaches aimed at ensuring that patients continue therapy for chronic conditions for long periods of time. Initially the patient was thought to be the source of the "problem of adherence". The idea of adherence is associated too closely with blame, be it of providers or patients ${ }^{11}$. Most of the study have shown the value of non adherence to oral diabetes medications ranges from $7 \%$ to $64 \%{ }^{87,88}$. The common reason for nonadherence in this study was simply that the patient's forgetfulness. In this study overall prevalence of adherence was 52\% which was consistent with the study carried out in Hungary having only $52.1 \%$ of the patients who had adherence to the antidiabetic medicines within the designated time frame in the prescribed dose, while $47.8 \%$ did not take the appropriate medicine as required..$^{89,90}$ In another community-based study undertaken in a rural primary health center area near Chennai (Madras), South India, nonadherence was seen in $57 \%$ of the total patients interviewed. ${ }^{73}$

Near resemblance was found in between study done in Jamaica and present study. Roter Debra L et al assessed self-care practices, and their relationships to glycaemic control in adults with DM in Jamaica was done and the rate of non-adherence was $55 \% .^{91-93}$

This present result also corresponded with the study done in Yale University School of Medicine, New Haven, Connecticut Retrospective analyses showing the adherence to OHA therapy ranged from 36 to $93 \%$ in patients remaining on treatment for 6-24 months.

Another cross-sectional study done at the Diabetic Clinic, Yala Provincial Hospital, Thailand assessed the factors affecting the compliance of diabetes mellitus patients such as socio-demographic characteristics, knowledge, perception and social support from family and health personnel. The finding of the study revealed that $58 \%$ of patients had good compliance and $42 \%$ had poor compliance ${ }^{94,95}$ which totally resembled to this current study.

The mean age in this study was $57 \pm 13$ years and the age distribution of the population was $10 \%$ for $<40$ years age group, $15 \%$ for $40-49$ years of age, $30 \%$ for $50-59$ years, $28.3 \%$ for 60-69 years of age and 17\% for more than 70 years of age. As it is a known fact that the prevalence of diabetes also increases with age likewise in this study majority of the patient were seen in 50-59 years of age.

The association of mortality and morbidity with complication was seen higher at old age. Around $42 \%$ of patients were found in more than 60 years of age in this present study. According to the DHS 2001, and Census 2001 , the proportion of population aged $>65$ is higher in Dharan.

In this study Most significant adherence was seen in group of respondents aged $>40$ years followed by up to 60 years. Here, 40 years or less aged respondents had $80 \%$ adherence to the medications followed by $56 \%$ when age increased up to 60years. Similar type of results was shown in study done in Mexico, Hungary, and India which comprised the trend of decreasing the adherence as the age increased.

Nearly one in every 2 respondents was not adhering to diabetes treatment. In addition, our respondents were from city areas, most of 
the respondents were ex-army personnel who were seem to be more aware about disease as well as stable economic status as compared to the normal local populations. Moreover, the presence of the tertiary level hospital (B.P.K.I.H.S) was an added benefit.

\section{Conclusion}

So summarizing this study, the present study found $52 \%$ patient adherence to the drug therapy. Although different prevalence of adherence were seen for each factor studied, most of the association was statistically significant. It could be concluded that, since the prevalence of adherence found in the present study was near to the prevalence that was recommended in the literature. The mean month for the duration of diabetes was 98.6 months.

More adherent was seen in female group which was not significant. According to the age group, most adherent group was of aged people $>40$ years. The most non adherent age group was in 60-69 years. So it can be said that as the age increased, the adherence gradually decreased excluding the age above $>70$ years. Age factor had shown direct relation with the non-adherence.

\section{Acknowledgments}

I would also like to acknowledge Dr. Vijay K. Khanal and Dr. Shyam S. Budhathoki, Dr. Dev Limbu and Mr. Saroj Wagle who helped during sample collection.

\section{References}

1. Sabate E.WHO Adherence Meeting Report. Geneva, World Health Organization.2001.
2. Sackett D et al. Patient compliance with antihypertensive regimens. Patient Counselling \& Health Education. 1978; 11:18-21.

3. Farmer KC.Methods for measuring and monitoring medication regimen adherence in clinical trials and clinical practice. Clinical Therapeutics. 1999; 21:1074-1090.

4. DiMatteo MR, DiNicola DD. Achieving patient compliance. New York, Pergamon; 1982.

5. Norell SE.Accuracy of patient interviews and estimates by clinical staff in determining medication compliance. Social Science \& Medicine - Part E, Medical Psychology, 1981; 15:57-61.

6. Cramer JA,Mattson RH.Monitoring compliance with antiepileptic drug therapy. In: Cramer JA, Spilker B, eds. Patient compliance in medical practice and clinical trials. New York, Raven Press, 1991;123-137.

7. Spector SL et al. Compliance of patients with asthma with an experimental aerosolized medication: implications for controlled clinical trials. Journal of Allergy \& Clinical Immunology, 1986; 77:65-70.

8. Morisky DE, Green LW, Levine DM. Concurrent and predictive validity of a selfreported measure of medication adherence. Medical Care, 1986; 24:67-74.

9. Freudenheim JL. A review of study designs and methods of dietary assessment in nutritional epidemiology of chronic disease. Journal of Nutrition, 1993; 123:401-405.

10. Sumartojo E. When tuberculosis treatment fails A social behavioral account of patient adherence. American Review of Respiratory Disease, 1993; 147:1311-1320.

11. World Health Organization. (2003). Adherence to long-term therapies: evidence for action. Ret Balkrishnana, R. (2005). The importance of medication adherence in improving chronicdisease related outcomes: what we know and what we need to further know. Medical Care 43(6) $2005 ; 517-520$.

12. The Centers for Disease Control and Prevention. National diabetes fact sheet: National 
estimates and general information on diabetes in the United States. Revised edition. Atlanta, GA, US Department of Health and Human Services, Centers for Disease Control and Prevention; 1998.

13. Fauci, Braunwald, Kasper, Hauser, Longo Jameson, Loscalzo. Harrison's Principle of Internal Medicine $17^{\text {th }}$ edition.

14. Cramer JA. A systematic review of adherence with medications for diabetes. Diabetes Care. 2004; 27(5):1218-1224.

15. Dailey G, Kim MS, Lian JF. Patient compliance and persistence with antihyperglycemic drug regimens: evaluation of a Medicaid patient population with type 2 diabetes mellitus. Clin Ther. 2001; 23(8):1311-1320.

16. Hungarian Central Statistical Office (homepage on the Internet). Counted population 2004. Budapest, Hungarian Central Statistical Office;2004.

17. Hungarian Gallup Organization (homepage on the Internet). National Health Interview Survey Hungary. Hungarian Gallup Organization; 2005.

18. Annette Winkler, Adrian U. Teuscher et al. Monitoring adherence to prescribed medication in type 2 diabetic patients treated with sulfonylureas. Swiss Med Wkly. 2002; 132:379-385.
19. Roter, Debra L. DrPH; Hall, Judith A; Merisca, Rolande; Nordstrom Beth,Effectiveness of Interventions to Improve Patient Compliance: A Meta-Analysis. Medical Care.1998; 36(8):1138-1161.

20. Julienne K. Kirk, Pharm.D., Jessica E. Poirier, B.S., Michelle G. Mattox, Pharm. D., Perry M. Thomas, and Robert Michielutte. Compliance With National Guidelines in Patients With Diabetes in a Family Practice Clinic Pharmacotherapy; 2003.

21. EM Duff, A O'Connor, N McFarlaneAnderson, YB Wint, EY Bailey, RA WrightPascoe. Self-Care, Compliance and Glycaemic Control in Jamaican Adults with Diabetes Mellitus. West Indian Med J. 2006; 55 (4): 232.

22. Boccuzzi SJ, Wogen J, Fox J, Sung JCY, Shah AB, Kim J. Utilization of oral hypoglycemic agents in a drug-insured U.S. population. Diabetes Care 2001; 24:1411-15.

23. R. Norlaila Binti Awang. Factors affecting compliance of diabetes mellitus patients attending the diabetic clinic,Yala provincial hospital, Thailand, Mahidol University ASEAN Institute for health development.

Address of Correspondence: Dr. Bi ay Thapa, Lecturer, Department of Community Medicine, Nobel Medical College, Biratnagar, Nepal.E-mail: tbijay@hotmail.com 